Dossier Anthropology on Latin America and the Caribbean today:

New Theoretical and Methodological Challenges

\title{
La Antropología frente a la racialización de los procesos político-electorales en México
}

\author{
Cristina Oehmichen-Bazán \\ 'Instituto de Investigaciones Antropológicas, \\ Universidad Nacional Autónoma de México (UNAM), México
}

\section{Resumen}

Este artículo tiene el objetivo de analizar, desde una perspectiva antropológica, el racismo y los procesos de racialización y polarización social en México, a partir de las prácticas discursivas y publicidad electoral llevadas a cabo con motivo de los comicios de junio de 2021. Se plantea que el uso de estereotipos racistas y clasistas, ampliamente difundidos en la campaña electoral, forman parte de determinados marcos de referencia primarios que funcionan como esquemas de interpretación de la realidad social y son puestos a prueba en la contienda política. Dichos marcos constituyen esquemas de percepción e interpretación que permiten a los sujetos reafirmar su propia identidad, distinguirse y orientar su actuar más allá de la contienda electoral.

Palabras clave: racismo, racialización, elecciones, polarización, México. 


\title{
Anthropology in the face of racialization of the political-electoral processes in Mexico
}

\begin{abstract}
This article aims to analyze the racism and the processes of racialization and social polarization in Mexico from an anthropological perspective. The analysis is based on the study of discursive practices and electoral advertising carried out on the occasion of the June 2021 elections. It is proposed that the use of racist and classist stereotypes widely disseminated in the electoral campaign are part of certain primary frames of reference that function as interpretation schemes of social reality, which are put to the test in the political contest. These frameworks constitute schemes of perception and interpretation, which allow subjects to reaffirm their own identity, distinguish themselves and guide their actions beyond the electoral contest.
\end{abstract}

Keywords: racism, racialization, elections, polarization, México.

\section{A antropologia ante a racialização dos processos políticos eleitorais no México}

\section{Resumo}

Este artigo tem como objetivo analisar o racismo e os processos de racialização e polarização social no México a partir de uma perspectiva antropológica. A análise baseia-se no estudo das práticas discursivas e da propaganda eleitoral realizada durante as eleições de junho de 2021. Argumenta que o uso de estereótipos racistas e classistas amplamente disseminados na campanha eleitoral faça parte de certos referenciais primários que funcionam como esquemas de interpretação da realidade social, que são postos à prova na disputa política. Esses referenciais constituem esquemas de percepção e interpretação que permitem aos sujeitos reafirmar sua própria identidade, distinguir-se e orientar suas ações para além da disputa eleitoral.

Palavras-chave: racismo, racialização, eleições, polarização, México. 


\title{
La Antropología frente a la racialización de los procesos político-electorales en México
}

\author{
Cristina Oehmichen-Bazán
}

\section{Introducción}

El 6 de junio de 2021 se llevaron a cabo los comicios en las 32 entidades federativas del país para elegir a 500 diputados federales, de los cuales 300 fueron electos por mayoría simple y 200 por el principio de representación proporcional. Además, se eligieron 15 gobernadores, se renovaron 30 congresos locales y alrededor de 2000 presidencias municipales.

La campaña electoral, iniciada en septiembre de 2020, se basó la difusión de imágenes acompañadas de eslogan publicitarios más que en la discusión a fondo de las propuestas de los diferentes partidos y candidatos. Al igual que en ocasiones anteriores, los diferentes partidos trataban de "vender" una imagen y ganar el voto de la ciudadanía. Para ello, la propaganda se reforzó con la postulación de celebridades de los deportes y del espectáculo. El nivel de discusión política descendió a los ataques personales y la contienda se polarizó entre los 10 partidos políticos que se agruparon en dos coaliciones: “Va por México", que agrupó a los partidos Revolucionario Institucional (PRI), Acción Nacional (PAN) y el de la Revolución Democrática (PRD). La otra coalición, denominada "Juntos hacemos historia", estuvo integrada por el Movimiento de Regeneración Nacional (MORENA), el Partido del Trabajo (PT) y el Partido Verde Ecologista de México (PVEM). Además de estas dos coaliciones participaron en la contienda el partido Movimiento Ciudadano y tres agrupaciones de reciente creación: el Partido Encuentro Solidario; Redes Sociales Progresistas; y, Fuerza por México, los tres creados en el último cuatrimestre de 2020.

Durante la campaña 91 políticos y funcionarios públicos fueron asesinados y otros más sufrieron diferentes tipos de agresiones: amenazas, infracciones contra la dignidad, secuestro, atentados contra familiares, robo con o sin violencia, tentativa de homicidio, daño a la propiedad, despojo de oficinas y lesiones, entre otras (Etellekt, 2021). El gobierno federal puso en marcha un operativo para proteger a los candidatos que habían sido amenazados por el crimen organizado y promovió una estrategia para la protección de los 21,000 aspirantes a puestos de elección popular, que incluyó mesas de trabajo y el reforzamiento de la seguridad en estados y municipios considerados de alto riesgo.

En este contexto, la contienda política altamente polarizada, también se racializó. Al igual que en elecciones anteriores, se utilizaron estereotipos negativos asociados a lo indígena y al universo simbólico de estereotipos que se les atribuyen: la pobreza, la ruralidad, el atraso, la ignorancia. Dicha visión, utilizada por la derecha radical para estigmatizar a los movimientos sociales y candidatos de la izquierda, ya había sido utilizada en anteriores elecciones. Esta se relaciona con los viejos temores de algunos grupos empresariales y eclesiales que llamaron a no votar por el partido Morena, pues supuestamente convertiría a México en una nueva Cuba o Venezuela. En esa misma tónica, ciertos discursos anticomunistas también se difundieron y aparecieron como una interpretación trasnochada de la Guerra Fría. Ante la falta de otros elementos y de una versión más 
actualizada de demonización de los movimientos sociales, la hipotética amenaza comunista fue reforzada con la promoción del miedo al "populismo".

Los grupos de la derecha antagonizaron contra las políticas redistributivas, tales como las pensiones a adultos mayores, becas para estudiantes de escasos recursos o becas de capacitación para jóvenes, calificándolas de "populistas". En esa dinámica se utilizaron los prejuicios clasistas y racistas que tradicionalmente han utilizado ciertos sectores de las élites para calificar a los indígenas y, junto con ellos, a los sectores populares que no se reconocen a sí mismos como indígenas, pero comparten ciertas características somáticas (como el color de la piel) y una pertenencia de clase. Durante los procesos político-electorales los han llamado "nacos", "morenacos" o "chairos". Estos términos se utilizan en referencia a lo indígena y lo popular, y han contribuido a reproducir una identidad minusvalorada de dichos sectores. Son palabras despectivas que expresan un clasiracismo muy arraigado en la sociedad mexicana. Forman parte del lenguaje cotidiano utilizado por diferentes sectores en pequeños círculos, como la familia, la escuela, grupos de amigos y otros espacios de socialización en las relaciones cara a cara. En ese sentido, se trataba de un racismo "no-discursivo" (Van Dijk, 2007) que se había ubicado en el terreno de lo implícito, pues no se había utilizado abiertamente en la esfera pública por no ser "políticamente correcto". Esta situación cambió cuando la vida política se pluralizó y el PRI dejó de ser el partido único. Cuando se abrió la competencia electoral, el racismo discursivo emergió a la esfera pública y puso al desnudo su contenido altamente segregacionista y excluyente. Frente a ello, el Instituto Nacional Electoral (INE) creo áreas enfocadas a la inclusión y a la no discriminación, pero sus acciones han estado reducidas a la revisión de acciones afirmativas a nivel representativo (cuotas electorales) y al establecimiento de guías para garantizar el voto sin discriminación. ${ }^{2}$

Hasta ahora, la Antropología en México se ha preocupado por analizar el racismo y la discriminación que se ejerce contra las poblaciones indígenas y afrodescendientes (Bonfil, 1987; Quecha, 2017; Velázquez, 2016). Ha analizado también la xenofobia hacia los inmigrantes chinos (Treviño, 2005) y el odio hacia los judíos (Bokser, 2001; Yankelevich, 2014; Gall, 2016). No obstante, poco se ha reflexionado sobre la interrelación entre racismo y procesos políticos para el mantenimiento de la hegemonía y el uso que se hace de los estereotipos racistas y clasistas con fines electorales.

Por otra parte, si bien la Antropología ha analizado los procesos de democratización, pluralidad y cultura política en México (Tejera, 2005; Varela, 2005; Rodríguez, 2012; Gómez Tagle, 2013), los estudios no se han articulado aún con la investigación en torno a los fenómenos del racismo y exclusión y, menos aún, con la manera en que la derecha radical estructura sus discursos y prácticas clasi-racistas como parte de su estrategia electoral, como los que veremos más adelante.

El objetivo de este artículo, por tanto, es contribuir al análisis del racismo subyacente en las campañas electorales y la manera en que los prejuicios y estereotipos de corte racista y clasista son utilizados en elecciones democráticas.

Partimos de considerar que la racialización de los procesos político-electorales es un fenómeno que se ha venido presentando en diversos países de América Latina, una vez que las elecciones democráticas han permitido la expresión de la pluralidad política y social. La racialización es un proceso de adjudicación de atributos identitarios, generalmente negativos, en los cuales se asocia cierto fenotipo y/o pertenencia de clase con las propuestas políticas de cambio que presentan los y las candidatas y sus organizaciones.

\footnotetext{
1 Como parte de la campaña para infundir el miedo, en 2018 se transmitió por Amazon Prime la serie "Populismo en América Latina". El entonces candidato de la izquierda a la Presidencia de México, Andrés Manuel López Obrador, aparecía como líder populista junto a otros líderes latinoamericanos como Hugo Chávez, de Venezuela, y Luis Inácio "Lula” da Silva, de Brasil. Debido a que se denunció que dicha serie tenía el objetivo de golpear la candidatura de López Obrador, las empresas de plataformas se negaron a transmitirla en México.

2 https:/|igualdad.ine.mx/igualdad/elecciones-sin-discriminacion/
} 
Los procesos de racialización son fenómenos complejos en los que intervienen los partidos políticos, pero también de manera preponderante los medios de comunicación. A través de las campañas electorales se producen y circulan formas simbólicas que reproducen y magnifican ciertos estereotipos clasistas y racistas a través de las "redes sociales" (principalmente Twitter y Facebook) en donde el anonimato permite mantener oculta la identidad de quienes promueven el racismo y otras formas de discriminación y exclusión social. Permiten también su reproducción magnificada a través de "granjas de bots" que operan desde la clandestinidad y que pueden generar noticias falsas, difundir prejuicios e incidir en el comportamiento del electorado.

Para analizar los procesos de racialización de la política acudimos al estudio de las prácticas discursivas y publicidad electoral llevada a cabo en México con motivo de los comicios de junio de 2021. Se plantea que los estereotipos clasistas y racistas usados en la campaña electoral forman parte de determinados marcos de referencia que operan como esquemas simplificados de interpretación de la realidad y permiten a los actores involucrados orientar las campañas políticas y definir su voto.

En la primera parte de este artículo se plantea la existencia de un giro global a la derecha que permite contextualizar la racialización que tienen lugar las campañas electorales y se plantean las coordenadas teóricas para su análisis. Se recupera la propuesta del frame analysis de Goffman y sus seguidores, y se aborda el tema del mestizaje y el racismo subyacente como parte de los marcos de referencia que operan como esquemas de simplificación de la realidad y sobre los cuales se abona a la racialización de la política.

A continuación se dan unas pinceladas de lo que ha sido la polarización política del país y se cuestiona si dicha polarización es el reflejo de la gran desigualdad social. En esta parte se analiza racialización en la contienda electoral. Se plantea el problema del clasismo y del racismo como dimensiones de análisis y como parte del discurso y prácticas de las dos principales fuerzas políticas del país: el Partido Acción Nacional (PAN) que representa a la derecha radical, tanto empresarial y como eclesial, y el partido Morena, que agrupa a un conjunto variopinto de movimientos sociales, políticos profesionales y mantiene un discurso de centro izquierda. Finalmente, se analiza la polarización política en términos de la racialización y el debate por parte de los grupos subalternos y se propone una vía para el análisis de estos fenómenos en América Latina.

La metodología utilizada en la elaboración de este articulo consistió en realizar seguimiento del proceso electoral de 2021 a través de la prensa escrita de los principales diarios de circulación nacional: El Universal, que es un periódico de centro cercano a la derecha; La Jornada, que se identifica con la izquierda; y Reforma, de la derecha. Además, se revisó el semanario Proceso. Asimismo, se acudió a las "redes sociales": Facebook, Twitter, Instagram y a dos grupos de Whattsapp con más de 50 personas que estuvieron muy activas durante la campaña electoral.

\section{El giro global a la derecha y los marcos de referencia}

La campaña electoral de 2021 se dio en un contexto global en el cual las nuevas derechas radicales emergen después de cuarenta años de política neoliberal (Coll y Urbán, 2019). Para unos, se trata del surgimiento de movimientos neofacistas (Weitz y Fenner, 2004) que se integran como una respuesta a las dislocaciones políticas y sociales producidos por la erosión de los Estados del bienestar en Europa y sus consecuencias en cuanto al desempleo y la precarización de la calidad de vida de la población experimentadas desde la década de 1990. Se considera que estas expresiones son una respuesta al asalto neoliberal liderado por Margaret Thatcher y Ronald Reagan, cuyos gobiernos hicieron de la desregulación uno de sus principales objetivos junto con la privatización, la reducción del gasto social y la bajada de los impuestos para los ricos, lo cual llevó a décadas de marginación y al surgimiento de fenómenos como el neofascismo y el fundamentalismo religioso (Achcar, 2021). 
El avance de la derecha radical ha sido atribuido también a la derrota histórica del socialismo real en la Unión Soviética a finales de los ochenta, que dejaron a la población mundial sin alternativas ante las políticas neoliberales. Los movimientos de la ultraderecha favorecieron la llegada al poder de empresarios exitosos que se postularon con éxito para sustituir a los viejos e ineficientes aparatos partidarios (casos de Trump en Estados Unidos, Macron en Francia, Vicente Fox en México). Dicho avance también se expresa en las escisiones xenófobas de la derecha tradicional (como el Partido Independiente del Reino Unido); en el surgimiento de partidos posfascistas (como Reagrupamiento Nacional, la Lega de Salvini); en la proliferación de movimientos islamófobos y en el surgimiento de agrupamientos anticomunistas como los de Bolsonaro en Brasil y Vox en España, entre otros (Coll y Urbán, 2019; Igreja y Negri, 2020).

Todos estos movimientos se gestan en un contexto de agudización de las desigualdades y se nutren de un nacionalismo exacerbado, en el rechazo a los migrantes, a las minorías nacionales y/o religiosas, y en un manejo de las emociones (Oehmichen, 2018; Abramsky, 2020) y de la posverdad. A ello habría que añadir, para el caso latinoamericano, la continua reedición de la polarización que se dio durante la “Guerra Fría”, expresada hasta hoy en el bloqueo económico y comercial a Cuba y Venezuela, y su construcción como ejes del mal en esta parte del mundo. El miedo al comunismo, a vivir "en la pobreza como Cuba" y en la "falta de democracia" y el autoritarismo de "dictadores" latinoamericanos, conformaron una mezcla discursiva para lanzar, contra los movimientos y partidos de centro izquierda, una andanada de ataques que polarizan a la sociedad a la vez que obnubilan la discusión política de fondo. La propaganda negativa para descalificar a los líderes de la oposición o candidatos de la izquierda ha sido un recurso frecuentemente utilizado en América Latina, en donde Cuba y Venezuela aparecen reiteradamente como los objetivos a atacar y con los cuales se busca asociar a los candidatos de los movimientos democráticos (Moreno y Corres, 2020).

El uso de viejos estereotipos empleados durante la "Guerra Fría" constituyen los marcos de referencia que permiten enfocar el análisis. Para Goffman (2006), los marcos de referencia son discursos producidos por los sujetos sociales para interpretar, argumentar y difundir un posicionamiento ante una situación determinada. Dichos marcos constituyen esquemas conceptuales simplificados que permiten a los actores atribuir significados a los diferentes fenómenos que se les presentan, a la vez que les permite reafirmar su identidad, definir problemas y actuar. Para Goffman, los marcos no se quedan en la mente o en el discurso de los sujetos, sino que, por el contrario, son marcos de la experiencia. En este sentido, conforman esquemas de interpretación y de acción. Un sujeto puede tener más de un marco de referencia primario y estos pueden variar en el grado de su organización. "Algunos son claramente presentables como un sistema de entidades, postulados y reglas; otros -la mayoría- parecen no tener una forma articulada visible, aportando solo una tradición de comprensión, un enfoque, una perspectiva" (Goffman, 2006: 23). Pero aun a pesar de ello, cualquiera que sea su grado de organización, todo marco de referencia "permite a su usuario situar, percibir, identificar y etiquetar un número aparentemente infinito de sucesos concretos definidos en sus términos” (Goffman, 2006: 23).

Los marcos de referencia son el resultado de procesos de interpretación y organización de la experiencia, a partir de los cuales el sujeto selecciona ideas, creencias y valores impregnados de la intencionalidad práctica, con la cual le da sentido a sus interacciones sociales. De ahí que la experiencia del trato con la alteridad (indígena, afrodescendiente, judía o inmigrante) forma parte de la experiencia cotidiana y una propuesta política puede darle un sentido a dicha experiencia y crear una forma plausible de interpretación de la realidad social.

A través de los marcos, los sujetos sociales orientan su acción y seleccionan aquellas formas simbólicas que actúan como matrices de significados o esquemas de interpretación de la realidad social, a través de la selección, codificación e interpretación de una realidad común.

El análisis de la contienda electoral de México en 2021 sugiere la existencia de al menos dos marcos de referencia articuladores o dominantes, sin que esto signifique una reducción a dicotomías rígidas entre una derecha conservadora y una propuesta de centro izquierda. Estas no son las únicas propuestas, aunque sí las más 
notables y aglutinantes. Por un lado, la propuesta de la derecha cuyo marco de referencia alude al "comunismo" para evitar, en lo posible, el regreso del Estado como actor fundamental en la regulación de los procesos económicos, se hace patente. Todo lo que sea devolver al Estado ciertas funciones sociales redistributivas es considerado como una forma de transitar al socialismo o, en el mejor de los casos, como "populismo". En el otro extremo se encuentra el marco de los movimientos de centro izquierda que pugnan por contar con una política redistributiva y el retorno del papel central del Estado en dicho proceso.

La similitud que guarda el proceso político mexicano con otros casos en Latinoamérica nos lleva a considerar que, en las campañas político - electorales, los marcos de referencia son muy similares, trátese de Bolivia, Perú, Argentina, Brasil o México. Se trata de políticas globales que se expresan en una crisis del modelo neoliberal de acumulación, que han llevado a la sociedad mundial a la polarización económica y a la depauperación de la calidad de vida de las mayorías. En este contexto, al discurso de la derecha radical enfocado a combatir al "populismo" se añaden un apego fuerte a la religiosidad, una reivindicación histórica anclada en el pasado colonial, una posición contraria a los derechos reproductivos de las mujeres y un abierto rechazo a los derechos de la comunidad LGTB.

\section{La polarización de las campañas}

En las elecciones mexicanas de 2021, las agrupaciones de la derecha enarbolaron un discurso en el que asocia al presidente Andrés Manuel López Obrador y a su partido (Morena) con la “dictadura” y el socialismo, quien supuestamente sigue un modelo similar al de Fidel Castro y Hugo Chávez. Asimismo, se difundieron un conjunto de estereotipos discriminatorios asociados a lo indígena, a las personas de color y a los pobres. Uno de los políticos más destacados de esta corriente, el excandidato presidencial Gabriel Quadri, señaló en su cuenta de Twitter que "Si México no tuviera que cargar con Guerrero, Oaxaca y Chiapas, sería un país de desarrollo medio y potencia emergente...”. Su opinión fue calificada de racista, pero lejos de disculparse, el autor de estas palabras culpó a los gobiernos estatales de poner trabas para la inversión privada en sus estados (Yañez, 2019). Cabe señalar que en los estos tres estados mencionados se concentra un alto porcentaje de población indígena del país.

El racismo, que había permanecido semioculto bajo la noción de mestizaje, estaba latente y ubicado en el terreno de lo implícito. Hasta hoy, ha sido políticamente incorrecto mostrarse como racista en un país que ha reivindicado su ancestralidad indígena y que mayoritariamente se asume como mestizo. Ser mestizo encarna la propuesta de integración de las amplias mayorías de la población a un proyecto de Nación, el de la "raza cósmica" resultado de la fusión de razas y culturas, el cual para la década de 1970 comenzó a ser cuestionado por un movimiento indígenas cada vez más plural y vigoroso. Los pueblos indígenas reivindicaron su derecho a proteger y desarrollar sus lenguas, culturas, tradiciones y formas de organización social, y a contar con derechos políticos sobre sus territorios (Bonfil, 1987; Bartra y Otero 2008). A las luchas indígenas se han venido a sumar otras acciones por el reconocimiento, a través de la etnización y la racialización reivindicativa, como ha venido ocurriendo en el caso de los pueblos afrodescendientes, invisibilizados en el discurso del mestizaje (Hoffmann, 2008).

El mestizo, como sujeto fundante de la construcción cultural de la Nación (Serrano, 2004), contribuiría de manera determinante a la conformación de una identidad nacional que se presentaba en oposición a los españoles del periodo colonial, a los franceses que en el siglo XIX invadieron a México e impusieron a un emperador europeo, o frente a los estadounidenses que también invadieron al país a inicios del siglo XX. El discurso del mestizaje va unido al nacionalismo que permite aglutinar a amplios sectores de la población que habían sido segregados y excluidos, tanto del poder económico como político. El mestizaje, como propuesta política y cultural, fue promovido junto con una serie de cambios que se presentaron como resultado de 
la Revolución Mexicana de 1910-1917, entre ellos: el reparto agrario, la abolición del trabajo forzoso, y una normatividad que velaba por los derechos laborales de los trabajadores, entre otros. Dicha política fue difundida a través de la escuela y el sistema de educación pública desde la década de 1930 y a lo largo del siglo XX. Bajo el precepto de igualdad de los mexicanos fueron abolidas las distinciones de casta y la segregación racial, aunque, por otro lado, la ideología del mestizaje ocultaba las grandes desigualdades de clase y excluía a "los otros" internos, los indígenas, como sujetos de derechos culturales y políticos, en tanto que los afrodescendientes eran relativamente invisibilizados.

En otras palabras, el mestizaje se planteó como la mejor vía de integración de las mayorías a la Nación, pero encubrió las desigualdades de clase y las formas de discriminación étnica y racial subyacentes. En 2001, el movimiento zapatista hacía notar que la exclusión de los indígenas no sólo obedecía al hecho de compartir otras culturas, sino que también había otras razones, como el fenotipo, por las cuales eran discriminados y excluidos. En la marcha de "Los hombres del color de la tierra", por primera vez el movimiento indígena asumía de manera explícita una reivindicación en tanto "raza" y convocaba a los no-indígenas a sumarse a su movimiento. Con ello mostraba la exclusión de las personas con fenotipos indígenas, de tez morena, en un país predominantemente identificado como mestizo.

Pocos años después, otro movimiento popular reivindicaría sus raíces indígenas. En 1989 nacía el Partido de la Revolución Democrática (PRD), a partir de una escisión del PRI y la fusión de organizaciones de la izquierda histórica de México (los partidos Comunista Mexicano y el Mexicano de los Trabajadores, así como organizaciones guerrilleras que recibieron amnistía en 1977). El PRD se definía como un partido democrático y de izquierda. También se autodefinía como el "partido del sol azteca", con lo cual enfatizaba su orientación nacionalista y reivindicaba sus raíces indígenas. En 2010, como resultado de una escisión del PRD nació el partido Movimiento de Regeneración Nacional (Morena) cuyo ideario político retoma las banderas nacionalistas y de izquierda. Su nombre es una obvia identificación racial que alude a los sectores de piel morena. Cabe preguntarse si partido Morena es la expresión política del mestizaje con el que se identifican amplias capas de la población, en donde el ser mestizo ha sido por décadas sinónimo de mexicanidad.

En 2018, ya como presidente electo, López Obrador se refería en sus discursos a las clases altas y élites intelectuales como "fifís". Ser "fifí" significa, de acuerdo con la jerga popular, pertenecer a las clases altas, blancas y privilegiadas del país. Son fifís también los "juniors conservadores que fingen ser liberales" (Aristegui Noticias, 2018). En contraparte, los miembros de Morena y seguidores de López Obrador se les había puesto el sobrenombre de "chairos". La palabra "chairo" según el lingüista Luis Fernando Lara, surge del habla entre carpinteros y carniceros que utilizan la "chaira", una barra dentada que se usa para afilar sus instrumentos. "La chaira es una metáfora del falo", y el 'chairo' "es el que se masturba” (Miselem, 2019). Ambos términos, fifí y chairo, tienen una connotación sexual homofóbica, pues el término fifí alude a un hombre elegante, amanerado y homosexual, cuya figura se hizo popular a inicios del siglo XX.

Por su parte, entre los candidatos de la derecha, representada por el Partido Acción Nacional (PAN) y algunas asociaciones civiles mostraban el entrelazamiento entre la ideología racista y la propaganda políticoelectoral. Desde 2006 habían advertido que el candidato de la oposición, López Obrador, que contendía desde entonces por la presidencia, era un "Peligro para México". Este eslogan, promovido por el PAN y difundido ampliamente por los medios de comunicación, vertebró una campaña sucia tanto en las elecciones de 2006 como en las de 2012 y 2018. Diseñada por el consultor político Antonio Solá y difundida ampliamente en spots publicitarios de radio y televisión, esta campaña negativa tuvo gran impacto en aquella ocasión.

3 Se dice que Antonio Sola ha asesorado 450 campañas electorales. Ha asesorado a varios mandatarios africanos, a los republicanos en Estados Unidos, al Partido Popular en España. Jacobo García, El País, 28 de agosto de 2020. 
El tribunal electoral declaró el triunfo del candidato del PAN, Felipe Calderón Hinojosa. Para López Obrador y el movimiento que lo respaldaba, hubo fraude electoral, pues según las cifras oficiales, había perdido la elección por menos de una décima de fracción. El "peligro para México" consistía en que, de ganar López Obrador la presidencia, llevaría al país a una situación de crisis, desempleo, pérdida del patrimonio de los mexicanos. En términos políticos, se le identificaba con Hugo Chávez y se afirmaba que llevaría al país a la dictadura. Algunos investigadores consideran que fue el miedo, más que el voto informado, lo que le dio el triunfo al conservador PAN y a su candidato (Hiller, 2011; Treviño, 2009; Gutiérrez, 2007). ${ }^{4}$ Esta campaña de miedo se repitió nuevamente en las elecciones presidenciales de 2012 y 2018, solo que en esta última ocasión no tuvo el efecto anterior, por el contrario, tuvo un triunfo arrollador (Estainou, 2019) al ganar la presidencia por abrumadora mayoría en las elecciones presidenciales más concurridas de la historia (Guzmán, 2019).

\section{La mestizofilia, proyanquismo y el racismo subyacente}

El mestizaje es un proceso más complejo que lo que aparenta ser. En México, al igual que en otros países latinoamericanos, la ideología del mestizaje logró ocultar por décadas el racismo subyacente, tanto en el discurso oficial como en el quehacer académico. Ya desde el siglo XIX se observaba cierto acuerdo en reivindicar el mestizaje, aunque había divergencias sobre el tipo de ciudadano mestizo que se buscaba. Según Basave (1992), entonces había un tipo de 'mestizofilia blanca' que apuntaba a la mezcla que tiende a favorecer el blanqueamiento de la población, y otra que según López-Beltrán y García Deister (2013) es una 'mestizofilia morena', que resulta de incorporar a la población indígena a la nación mediante la mezcla biológica y la aculturación educativa. Esta segunda opción, de acuerdo con estos autores, fue la predominante en el siglo XX. El mestizo moreno sería reivindicado por el discurso nacionalista y se convertiría en el sujeto que encarnaba el espíritu de la nación.

El mestizaje que se logra a través de la procreación y se reconoce a través de las relaciones de parentesco y matrimonio, tiene complejidades que han sido hasta hoy poco estudiadas. Esto es así porque el mestizaje no ha sido objeto de interés de parte de los antropólogos y de otros científicos sociales. "Al moverse el mestizo al centro de las indagaciones sobre la identidad mexicana, la atención de la antropología mexicana poco a poco se concentró en la polaridad indio-mestizo y en la ladinización y asimilación de lo indígena como solución a las rudezas que dicha polaridad engendraba" (López-Beltrán y García Deister, 2013: 393). El proyecto indigenista promovido por el Estado, dirigido a aculturar a la población indígena para integrarla a la corriente predominante del mestizaje, tendió a homogeneizar tanto a los indígenas como a los mestizos y proponerlos como parte de una relación dicotómica, que finalmente culminaría con la eliminación de las fronteras que separaban a estas categorías. La ideología del mestizaje ocultó las diferencias de clase en el país, así como la diversidad étnica y cultural. Pero, por otro lado, la reflexión académica sobre el tipo de mestizaje que se promovía en el país y los temas relacionados con las identidades raciales, étnicas y regionales fue prácticamente echa a un lado ante el interés que merecía la relación indomestiza.

De ahí que el estudio de los distintos mestizajes, del racismo y la blanquitud sea una tarea por hacer. En todas las clases sociales, por ejemplo, parece haber cierto acuerdo que tiende a enaltecer a cierto tipo de personas según sus características somáticas, como serían el color de la piel, la forma del cráneo, el tipo de cabello, y a colocarlas por encima de otras. En México, serían los blancos por encima de los mestizos morenos, los mestizos por encima de los indígenas, a la vez que se ignoraba o invisibilizaba a los afrodescendientes.

4 Entre otros análisis sobre la propaganda negativa y sus efectos en la elección presidencial del 2006 se encuentran: Jenaro Villamil y Julio Scherer Ibarra, Los medios y los jueces. La guerra sucia de 2006, México, Grijalbo, 2007; Salvador Camarena y Jorge Zepeda Patterson, El presidente electo. Instructivo para sobrevivir a Calderón y su gobierno, México, Planeta, 2007; Jorge Gil Olmos y J. Jesús Esquivel, “Dick, el sucio”, Proceso, 10 de septiembre de 2006; Álvaro Delgado, "Castañeda: Yo propuse la estrategia del miedo", Proceso, 22 de julio de 2007. 
Esta visión difundida y reivindicada por las élites a través de los medios de comunicación y de las industrias culturales ha hecho que, si bien la población mayoritaria se autodefina como mestiza, sea frecuente que se busque en las relaciones de matrimonio y parentesco "mejorar la raza" (Navarrete, 2016: 70). Esto significa que hay ciertas aspiraciones al blanqueamiento social e interés de subir en la escala social a través del mestizaje blanco. Navarrete (2016) advierte el entrecruzamiento entre fenotipo y clase social y señala que ciertos sectores de la clase media invierten grandes recursos en ropa fina y cosméticos para simular pertenecer a las clases sociales "supuestamente más cultas o elevadas económicamente" pues el simple hecho de seguir los dictados de la moda tiene un "efecto blanqueador" que puede convertir al moreno en blanco o "güero".

Ahora es importante observar la manera en que operan los procesos de racialización, esto es, de invención de atributos que tienen como significante principal al cuerpo humano, particularmente el color de la piel, aunque éste no sea el único elemento para marcar distinciones y fronteras. El concepto de racialización, puede ser definido como un proceso de percepción, interpretación y acción que tiende a seleccionar ciertos aspectos fenotípicos a los que se les colocan ciertos atributos de identidad. Al entenderlo así, podemos ver que la racialización tiene como significante el color de la piel, y sirve de base de sustento a un conjunto de significados que pueden variar históricamente, pero mantienen la misma estructura de significación. Verlo de esta manera puede ser útil para explicar las maneras en las que el racismo sigue operando, se reinventa y se modifica sin que haya necesariamente una noción clara sobre la separación de la sociedad a partir de la "raza".

Todo lo anterior es interesante en la apuesta política. Hay sectores que se identifican con las clases altas y buscan emularlas. El discurso político de las élites busca atraer a estos sectores. No es casual que el candidato del PAN a la presidencia en las elecciones de 2018 haya sido Ricardo Anaya, un joven emprendedor que radicaba con su esposa e hijos en Estados Unidos y cuyos discursos mostraban la fluidez en el manejo de los idiomas inglés y francés. La arenga política en esas lenguas fue motivo de memes y de burlas, por un lado, pero también de reivindicaciones en los medios de comunicación que exhibían el monolingüismo en castellano (supuestamente mal pronunciado) de López Obrador. En 2006, Enrique Krauze señalaba en uno de sus artículos que este líder político es oriundo del estado de Tabasco, el cual es “...de aquella zona del Golfo de México, convierte las "eses” en "jotas"). En ese mismo artículo se dice sorprendido de que López Obrador no tuviera pasaporte para viajar al extranjero, y lo exhibía como muy limitado: "Era obvio que el mundo lo tenía sin cuidado. Su mundo era México. Y el mundo de su mundo era Tabasco" (Krauze, 2006).

Bajo ese mismo discurso, López Obrador, ahora como presidente, ha sido objeto de la crítica por algunos intelectuales y periodistas de la derecha porque no habla inglés. Ricardo Rocha, periodista del diario El Universal, en 2021, dijo en un Twitt "López Obrador no habla inglés; pero tampoco habla el lenguaje de Biden. Está claro que son dos estilos de gobierno que se anticipan no solo diferentes sino opuestos y hasta confrontados". De esta forma, el periodista buscaba un escollo para mostrar cierto distanciamiento de AMLO con el presidente recién electo, Joe Biden.

La racialización de personas, grupos, clases sociales, partidos políticos nos permite poner atención al proceso de esencialización en la construcción de identidades, como marcos de referencia que tienden a asociar la pertenencia de clase y el racismo. La racialización en el contexto mexicano, es un proceso dinámico que en la actualidad implica considerar un tipo de mestizaje blanco, asociado a otros símbolos de blancura en donde el apego a los valores estadounidenses, el uso fluido del inglés y/o del francés, tienen una connotación positiva, en detrimento de quienes sólo hablan castellano. Este esquema, forma parte de un proceso global que se inserta incluso en la academia, pues se considera que el lenguaje de la ciencia es el inglés.

La población mexicana habla castellano y más de 63 lenguas indígenas. La mayoría fue escolarizada en instituciones públicas, en donde no se capacita a los alumnos para tener un manejo fluido inglés. Este idioma no está entre sus objetivos ni se cuenta con la capacidad técnica y docente para lograrlo. 
Esto contrasta con los colegios particulares, en donde a los niños se les enseña desde pequeños a hablar, leer y escribir inglés. El manejo de ese idioma opera en determinados contextos como un marcador de clase que permite a las élites marcar su distancia respecto a los pobres, los "nacos", o los "chairos". La racialización es un proceso de legitimación de jerarquías sociales y construcción de alteridades negativas y estigmatizadas en donde "los "otros" son rechazados explícitamente de algunos lugares de prestigio, desde discotecas o locales elegantes de diversión nocturna (Iturriaga, 2015), pero también de espacios que cuentan con un "techo de cristal" en donde no hablar el idioma inglés se convierte en una limitación para acceder o prosperar en una carrera académica.

No siempre las formas de rechazo son evidentes. Hay formas sutiles de exclusión. "Los espacios emiten mensajes, contienen prescripciones, prohibiciones y posibilidades de orden interactivo que son inteligibles para sus concurrentes... La discriminación es auxiliar de la pobreza, desalienta, descalifica, reduce la voluntad de utilizar canales de ascenso económico y social" (Margulis y Urresti, 1998: 79).

Cabría pensar en analizar la manera en que el racismo y el clasismo constituyen para las élites, un mecanismo para marcar fronteras de clase y fortalecer su cohesión social, con base en una cultura del privilegio, tema que podría ser de gran interés para la Antropología. El racismo y el clasismo son la expresión de un trabajo constante, continuado y permanente de las élites, amplificada por los medios de comunicación. De ahí la importancia de retomar el frame analysis de Goffman, para ver la manera en que los marcos de referencia de las élites y de la izquierda se expresan a nivel microsociológico.

\section{La construcción de la "otredad"}

\section{a) La derecha radical: algunos antecedentes}

Hablar de derecha en México implica referirse a un conjunto heterogéneo, disperso y en ocasiones contradictorio en el que participan sujetos de muy diversos espacios sociales. Se encuentran principalmente en la Iglesia, en el aparato de gobierno, en los partidos políticos y en el empresariado. Tienen un papel destacado ciertos intelectuales y medios de comunicación como los diarios, las revistas y, sobre todo, las televisoras y organizaciones de la sociedad civil. A pesar de su dispersión y falta de cohesión orgánica, en momentos de crisis o de coyuntura que afectan a sus intereses, tienden a reagruparse (Pérez et al., 1991). Cuando tal eventualidad sucede, estos grupos actúan de manera conjunta. Cuentan con expresiones políticas estructuradas en torno al Partido Acción Nacional y con el apoyo de los medios de comunicación y algunos intelectuales. En 1982, por ejemplo, reaccionaron ante la nacionalización de la banca, oponiéndose a ello; para 1988 se aglutinaron para impedir la llegada a la presidencia de un candidato de la oposición de centroizquierda, Cuauhtémoc Cárdenas Solórzano. En las siguientes elecciones presidenciales llevadas a cabo en 2006, 2012 y 2018 se unieron para impedir la llegada de López Obrador a la presidencia. Este ha sido el tema que más cohesión les ha dado y si bien en sus filas convergen grupos antiaborto, Pro-Vida y los que se oponen al matrimonio igualitario, ha sido su oposición a López Obrador y a su partido, lo que más ha logrado aglutinarlos.

Entre ellos tienen un papel destacado algunos sectores de la Iglesia católica y su jerarquía. Con la reforma liberal del siglo XIX, la Iglesia católica vio reducido su poder e influencia. Con la promulgación de las Leyes de Reforma, perdió sus bienes y grandes latifundios, a la vez que se proclamó la separación de la Iglesia del Estado. Esta política llevó a los conservadores a patrocinar la intervención francesa y el trágico segundo imperio representado por Maximiliano de Habsburgo. Derrotados los intervencionistas franceses, arribó a la presidencia el general Porfirio Díaz, cuya agenda política mantuvo vivo el espíritu jacobino inspirado por el movimiento 
de Reforma. En esos años, los conservadores desplegaron un gran activismo a través de sociedades secretas católicas, que comenzaron a desarrollar actividades efectivas (Blancarte, 2018).

Entre las décadas de 1920 y 1930 se gestó un gran movimiento armado conservador, conocido como la Guerra Cristera o la Cristiada. La derecha radical religiosa y civil participó en la promoción de esta guerra, que en 1926 se alzó contra el gobierno del presidente Calles. Este movimiento buscaba conservar los privilegios que los diferentes sectores elitistas habían tenido desde la Colonia y para ello buscaban desestabilizar por diferentes medios a los gobiernos posrevolucionarios. Buscaban incitar a la sociedad mexicana a un levantamiento armado para defender los espacios de participación política que la Iglesia católica había perdido (García Cantú, 1997). ${ }^{5}$ A la Iglesia católica también se le atribuye la discriminación a las minorías religiosas, sexuales y étnicas (Monsiváis, 2008).

Después de la derrota del movimiento cristero, una paz negociada hizo posible mantener la relación entre la Iglesia y el Estado. Debido a que no pudo intervenir en asuntos de política, la jerarquía católica promovió la integración de grupos laicos pertenecientes a diversas congregaciones religiosas, que desde el cardenismo de la década de 1930 han realizado proselitismo político. A través de dichos grupos, la Iglesia ejercía presión a los gobiernos posrevolucionarios, expresando su rechazo a las reformas y políticas progresistas (Bernal, 2017).

Para la década de 1960, la Iglesia comenzaría a modificar su relación con el Estado, abandonando su repliegue y dando los primeros pasos para asumir un liderazgo político expreso. Para la década de 1980 ya participaba de manera más activa en la política. Si bien las negociaciones cupulares seguían siendo la forma en que se articulaba la relación Iglesia-Estado, la iglesia católica hacía un uso más intenso de los medios de comunicación y acudía a la movilización social. El cambio principal, sin embargo, se dio en 1992 con la aprobación de la Ley de Asociaciones Religiosas y Culto Público. Durante el gobierno de Carlos Salinas de Gortari, la Iglesia obtuvo su reconocimiento jurídico. También se instituyó un marco legal para normar las relaciones entre el Estado y las iglesias. A pesar de dicho reconocimiento, hasta hoy las iglesias mantienen algunas limitaciones, ya que los ministros de culto no pueden tener cargos políticos ni ser elegidos para puestos de elección popular. Tampoco pueden ser dueñas de medios de comunicación (Garma, 2020).

Un segundo bastión de los grupos conservadores se encuentra entre el empresariado norteño. Hasta la década de 1980 los empresarios y sus organizaciones cupulares se habían mantenido al margen de hacer intervenciones políticas directas o de participar abiertamente en la vida político - electoral. Por lo general, gestionaban sus demandas ante el Estado a través de las cámaras, consejos y confederaciones patronales y negociaban con el partido en el gobierno (el Partido Revolucionario Institucional, PRI) (Tirado 1984; 1990).

En la década de 1980 esta forma de operar cambió, pues ciertas organizaciones empresariales se radicalizaron en contra de decisiones del Estado, como fue la nacionalización de la banca ocurrida en 1982 (Pérez, et. Al 2015). Dicha radicalización se expresó en declaraciones públicas de las organizaciones empresariales y en la participación política abierta de varios empresarios a través del Partido Acción Nacional (PAN). Más adelante, en las elecciones presidenciales de 1988, las cúpulas empresariales impulsaron la candidatura de Manuel Clouthier, postulado para la presidencia de la República por el PAN. Esta fue la primera vez en que el empresariado participaba abiertamente con un candidato en las campañas políticas. Clouthier no ganó la presidencia, pero el empresariado logró que uno de sus miembros, el empresario Ernesto Ruffo, fuera electo como primer gobernador de un partido de oposición al gobernante PRI. Apoyaron su candidatura diversas organizaciones sociales de la derecha, como la Unión Nacional de Padres de Familia, el Ejército Democrático, el Frente de Solidaridad Empresarial, la Asociación Nacional Cívica Femenina, el Comité Pro-Defensa del Voto de Jalisco, entre otras (Pausic y Pérez, 1988: 19). En todo este trance, mención especial merece "El Yunque", organización

5 Para un estudio en profundidad de este movimiento, se puede consultar la obra de Jean Meyer (1973). 
ultraconservadora de corte paramilitar que, según diversos estudios, pretende hacerse del poder instaurar lo que denomina el "reino de Dios en la Tierra" (Delgado, 2003; Flores, 2021). ${ }^{6}$ Esta agrupación ha sido vista como una especie de "teocracia clerical" y acusada de integrar a "talibanes cristeros", que si bien sostiene posturas arcaicas, ha sabido adaptarse los cambios del país (Barranco, 2021). Los miembros de El Yunque han infiltrado a diversos partidos e instituciones gubernamentales, pero principalmente han actuado al amparo del PAN. En agosto de 2021, WikiLeaks dio a conocer 17 mil documentos que vinculan a El Yunque con miembros prominentes del PAN y de otros partidos, cámaras empresariales, instituciones educativas, y exhibieron la fuerte relación con la derecha franquista en España.?

Con la llegada a la presidencia de Carlos Salinas de Gortari (candidato del PRI), el gobierno mostró habilidad para neutralizar a las fuerzas empresariales opositoras. Para algunos, se trató más bien de un mayor acercamiento del Estado con los empresarios, quienes se vieron beneficiados con las privatizaciones de los recursos públicos y bienes propiedad de la nación. Con ello, algunos analistas consideran que inició un proceso de derechización de la entonces llamada "clase política" del país, que marcha a la par de la instauración de las políticas neoliberales que proclaman el "adelgazamiento" del Estado y la privatización de los bienes comunes (Oehmichen, 1999).

Un nuevo avance de la derecha radical se expresó en los comicios del año 2000 cuando por primera vez llegaba a la presidencia Vicente Fox, un ex gerente de la Coca Cola. Fox fue postulado por un grupo empresarial, conocido como "Amigos de Fox", el cual se había organizado al margen del PAN, pero finalmente logró conseguir su apoyo y ser postulado por dicho partido. Así, el PAN llegaba a la presidencia después de 70 años de gobierno por parte del PRI. La llegada de Fox podría analizarse como resultado de un proceso de transición democrática y alternancia política. Su llegada a la presidencia fue promovida por un bloque que articuló a grandes empresarios vinculados con sectores de la jerarquía católica y de la derecha empresarial de gran influencia en México.

En todo este proceso ha habido intelectuales han jugado un papel destacado en la conformación de los imaginarios políticos y en la estructuración de un discurso coherente, logrando integrar a los diferentes sectores conservadores y de la derecha radical. En 2006 se apresuraron a dar el triunfo en la elección presidencial al candidato del PAN, Felipe Calderón Hinojosa, a pesar de las impugnaciones y denuncias de fraude que hiciera el Partido de la Revolución Democrática. El 3 de agosto de ese año, 135 intelectuales publicaron en diversos medios un comunicado ${ }^{8}$, en el que aseguraban que no hubo fraude electoral, como denunciaba la oposición. "Fueron elecciones auténticas entre partidos y candidatos plurales. Ninguna fuerza política ganó todo y ninguna perdió todo. Nuestra votación nos obliga a vivir y convivir en la pluralidad”, dijeron (García-Vergara 2008). Entre los firmantes se encontraban las mismas personas que en 2018 se sumarían a los esfuerzos de la derecha radical para combatir las políticas "populistas" del gobierno de AMLO, quien había ganado las elecciones presidenciales por abrumadora mayoría.

\footnotetext{
6 La Organización Nacional del Yunque es una agrupación secreta de inspiración católica. Se ha dicho que reclutas jóvenes para adoctrinarlos y adiestrarlos en el combate físico e ideológico, con el fin de avanzar políticamente en la conquista del poder público. (Delgado, 2003)

7 Para más información, se pueden ver los programas de agosto de 2021 de Sacro y Profano, transmitidos por el Canal 11 de Televisión de la Ciudad de México. Se pueden consultar en el programa "Las conspiraciones del Yunque" transmitido el 4 de agosto de 2021. Puede verse en https:/youtu.be/xOhzAwinFNo; el programa del 18 de agosto de 2021 titulado "El Yunque, WikiLeaks y la ultraderecha internacional”, que está publicado en

https://youtu.be/L2n3mQ748Uk. Finalmente, el programa de El Chamuco TV dedicó su programa del 15 de agosto de 2021 a la influencia que ha tenido este grupo de la derecha radical en 50 países. Este puede verse en https:/|www.youtube.com/watch?v=yX10JDI2Ejs

8 El Universal, jueves 3 de agosto de 2006. Entre los firmantes se encuentran prominentes miembros de la academia, escritores, periodistas http://www. eluniversal.com.mx/notas/366445.html, (consultado el 13 de julio de 2021)
} 


\section{b) El “Mesías tropical”, los whitexicans y el "poder prieto}

La polarización en las elecciones presidenciales de 2006, 2012 y 2018 también se expresa en las elecciones intermedias, como en la del año 2021. El discurso político en que se manifiesta dicha polarización tiene una estructura de significados que se ha venido repitiendo en los últimos 30 años, y en la que participan más o menos entre los mismos sectores y actores políticos. Esta nos habla de una confrontación entre por lo menos dos visiones de país y dos modelos de desarrollo. En 2006, el lema del ahora presidente López Obrador había sido "Por el bien de todos, primero los pobres". Llamaba a reorientar el rumbo y llevar a cabo una política pública que apoyara a los pobres. Su campaña hacía referencia a la enorme polarización y pobreza que habían generado las políticas neoliberales en el país. Desde entonces, se había conformado un poderoso movimiento ciudadano en el que convergían los más amplios y heterogéneos sectores sociales. Se trata de una "confluencia heterogénea e inorgánica" que desde entonces estaba enfrentando "el embate colérico de los poderes fácticos y haciendo de López Obrador el líder indiscutible de la izquierda (Bartra, 2006).

De alguna manera, lo que se expresa en los comicios y en las contiendas electorales es un reflejo de la enorme polarización económica y social del país y la confrontación entre dos visiones de país. Se trata de una confrontación política que en unas ocasiones se expresa en términos de clase y con marcados tintes racistas con el que las élites buscan legitimar su poder. En 2018 López Obrador logra arrasar y ganar por abrumadora mayoría las elecciones, junto el partido Morena.

$\mathrm{El}_{3}$ de junio de 2021 se llevaron a cabo las elecciones intermedias que, como antes señalamos, habrían de renovar a la Cámara de Diputados, gubernaturas y presidencias municipales. En vísperas de los comicios, la revista británica The Economist, en un editorial dado a conocer mundialmente, calificó al presidente Andrés Manuel López Obrador de ser "un peligro para la democracia". La portada de la revista exhibe la figura del presidente mexicano con el logotipo de Petróleos Mexicanos, acompañado de un grupo de militares y un dedo que apunta hacia él, en un intento por retratarlo como un líder autoritario. El titular reza "falso mesías". En el primer párrafo de este editorial advierte que es "un peligro para la democracia" y pide a los mexicanos no votar por su partido, Morena, en las elecciones del 6 de junio.

El editorial señala que el presidente mexicano se aleja de las prácticas de otros "mandatarios populistas" como Viktor Orbán, de Hungría, Narendra Modi, de India y Jair Bolsonaro, de Brasil, pues AMLO “...no se burla de los homosexuales, no golpea a los musulmanes ni incita a sus partidarios a incendiar el Amazonas”. No obstante, agrega, habla en nombre de los pobres de México y lo acusa de polarizar la sociedad mexicana: "Divide a los mexicanos en dos grupos: el pueblo, que se refiere a quienes lo apoyan; y la élite, a la que denuncia, a menudo por sus nombres, como delincuentes y traidores a los que culpa de todos los problemas de México".

La revista británica recuperaba así el escrito que en 2006 había publicado el líder conservador Enrique Krauze, quien en ese tiempo había definido a López Obrador de la siguiente manera. "Tempranero como un gallo, rijoso símbolo con el que le gusta compararse, elusivo como el pejelagarto, típico pez de las aguas de Tabasco, del que proviene su sobrenombre." La alusión a los animales tropicales es más que evidente. En la construcción de la alteridad, generalmente se busca restar su humanidad al oponente y colocarlo en el lado de la naturaleza, en oposición a la cultura. Este extenso artículo dedicado a López Obrador circuló profusamente en los medios, fue refutado en aquel tiempo por Víctor M. Toledo (2006), cuya crítica ahora recupera para señalar que se trata de un "complejo montaje ideológico dirigido a generar temor entre las élites invocando los peligros de lo tropical, lo salvaje, lo selvático, lo pasional, percepción que proviene del racismo europeo" (Toledo, 2021).

Se destaca el texto de Krauze porque es uno de los más elaborados y representativos de la derecha radical, aunque no es el único. Bajo esa tónica otros intelectuales expresarían su rechazo a las políticas del presidente López Obrador, con expresiones que muestran un marcado sesgo racista y clasista. Algunas de estas expresiones son primero producidas y difundidas en Twitter y después retomadas por los medios, incluyendo la radio y la televisión. Entre las expresiones que hubo durante la contienda electoral de 2021 se encuentran las siguientes: 
José Woldenberg, ex presidente del Instituto Federal Electoral se refirió a los votantes como "perros de Pavlov", en referencia a una consulta popular sobre la posibilidad de llevar a juicio a los expresidentes ${ }^{9}$. En otro caso, el expresidente Felipe Calderón, en su cuenta de Twitter escribiría en referencia a una polémica con el presidente argentino que en México "decimos que la culpa no la tiene el indio, sino quien lo hace presidente" ${ }^{10}$. Asimismo, el ex presidente Vicente Fox criticaría el envío de vacunas de México a Guatemala indicando que "Cada vacuna que regalas puede ser un mexicano muerto" ". El comunicador de televisión y prominente vocero de la ultraderecha, Pedro Ferriz, escribiría en su cuenta de Twitter "tu vendrás de los indios: yo vengo de Adán y Eva". ${ }^{12}$ Esta muestra retrata la tónica con la que se expresaron los grupos conservadores, cuyos mensajes circularon junto con un amplio abanico de intervenciones, firmadas y anónimas, difundidas por todos los medios y multiplicadas en las "redes sociales".

En esta campaña participaron también figuras del espectáculo y la farándula, a quienes los medios les brindaron espacios en la televisión abierta y en la prensa escrita. Por ejemplo, la presidenta de Morena, Citlali Hernández, fue atacada por ser "gorda y traicionera", por parte de la actriz Laura Zapata. Su traición consistió, según la desconocida actriz, en recibir en México "al peruano Evo Morales" (sic). Parte de la campaña de desprestigio de los candidatos de Morena difundida por la televisión, consistió en imitar el habla de las personas de los sectores populares, que para ciertos actores son "morenacos". ${ }^{13}$ La actriz antes citada llamó a los miembros de Morena "malditos gatos zarrapastrosos". Estas expresiones ofensivas podrían pasar inadvertidas si no fuera por la amplificación que de ello hacen las televisoras y otros medios de comunicación.

De forma paralela y a manera de reivindicación auto afirmativa, en 2018 surgió en las redes sociales una etiqueta que describe de manera humorística las maneras de pensar y actuar de los sectores que se identifican con la derecha racista: "los Whitexicans". De acuerdo con Álvarez-Pimentel (2020), como respuesta a las campañas racistas se creaba el grupo de Twitter "Cosas de Whitexicans", también conocido como \#Whitexicans y @LosWhitexicans. Activado en octubre de 2018, @Los Whitexicans definió su página como un lugar para el “humor negro sobre gente blanca”. Un año después, contaba con más de doscientos mil seguidores. Su nombre surge de la fusión de la palabra inglesa White, que alude a la blanquitud como aspiración de un sector de la élite y de Mexicans, que hace una clara referencia a las élites por su tendencia a identificarse con las personas blancas de Estados Unidos. El objetivo es mostrar el racismo y el clasismo de la personas blancas y adineradas de México. No obstante, posiblemente esta estrategia no logre reducir las prácticas racistas.

En las redes sociales, el término Whitexicans fue retomado para acompañar fotografías de mexicanos paseando en ciudades extranjeras o comprando artículos de marcas lujosas o pronunciando algunas frases o dichos que denotan su carácter clasista y racista. El término alude a la manera en que una minoría privilegiada se cree superior a otros sectores sociales en México, más que a un tono de piel. También se refiere a personas que hacen uso de su privilegio de clase, sin consideración alguna a quienes no gozan de su situación. Es el caso, por ejemplo, de una fotografía en la cual una pareja retrata a un niño que está sentado en el piso que pide dinero mientras canta. Al pie de la fotografía (publicada en Twitter), un usuario señala que el problema no es que se trate de gente blanca, sino "...la falta de sensibilidad por las personas que menos tienen".

\footnotetext{
9 \#SuaveMatria: No es perrada, es pueblo informado, don José (Woldenberg)

https:/|regeneracion.mx/opinion-no-es-perrada-es-pueblo-informado-don-jose-woldenberg/

10 https://twitter.com/felipecalderon/status/1402712078641774592?lang=es

11 https:/www.radioformula.com.mx/noticias/20210624/cada-vacuna-que-regalas-puede-ser-un-mexicano-muerto-vicente-fox-sobre-donacion-de-dosis-a-guatemala|

12 https://www.google.com/search?source=univ\&tbm=isch\&q=Pedro+Ferriz+tu+vendras+de+los+indios+yo+vengo+de+Adan+y+Eva\&sa=X\&ve-

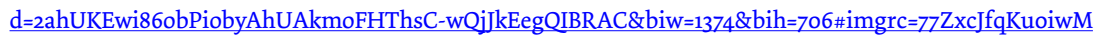

13 Ver programa Sin Censura, de Vicente Serrano, quien señala que las televisoras les abren el espacio a personajes del espectáculo para difundir estereotipos racistas https:|/mail.google.com/mail/u/o/?tab=rm\&ogbl\#inbox/FMfcgzGkXwHpvfRPlPxJntcvgVppDqjx?projector=1 (consultado el 22 de julio de 2021)
} 
Y añade que un Whitexican vive en una burbuja, carece de empatía puesto que no conoce a su país. Esas son "cosas de Whitexicans" ${ }^{14}$ Para julio de 2021 ya contaba con más de 320 mil seguidores.

Algunos personajes que se sintieron aludidos se quejaron de este apelativo, indicando que es racismo "inverso". Sin embargo, para la organización RacismoMX, el sitio "Cosas de Whitexicans" es "una sátira que sirve para reírse del poder de la blanquitud en México" y, señalan que no es equivalente a los términos racistas que se usan en contra de personas no blancas porque "no hay detrás el racismo que oprima a las personas blancas, como sí existe uno histórico que ha oprimido a poblaciones negras, indígenas y prietas". ${ }^{15}$ Quienes participan de este movimiento muestran a los grupos ultraconservadores vestidos con la bandera la bandera de Estados Unidos y señalan "Ni nosotros pudimos haber planeado una foto tan perfecta para esta cuenta". En otras imágenes critican la publicidad del diario Milenio, en que aparece una mujer que promueve "Maquillaje aesthetic para pieles morenas". En otra más aparece un joven blanco con dos amigos, sus "amigos morenitos, pues... Todo blanquito necesita a sus amigos morenitos" y otras por el estilo. Un meme más elocuente muestra a una mujer que se queja de no poder salir a la calle con sus "Louis Vuitton, Chanel, Burberry, Givenchy o zapatillas Christian Louboutin, o sea ¿que pedo?”

En 2021, surgieron los 'hashtags' \#PoderPrieto y \#DondeHayPrieturaHaySabrosura, en donde artistas y usuarios de las redes sociales publicaron imágenes en las que muestran su piel morena y reivindican su belleza: 'Mi piel se respeta, mi piel suda, mi piel resuena, en mi piel no hay duda, mi piel ama, mi piel es pura sabrosura' ${ }^{16}$ En este participan actores mexicanos famosos escritores, periodistas y otros usuarios, como una muestra de autoafirmación y un espacio para combatir el racismo en México. Cabría preguntarse, sin embargo, si una racialización auto afirmativa contribuye efectivamente a combatir el racismo o, por el contrario, la reproduce.

Los mensajes que se envían por Twitter, Facebook, Instagram y, muy frecuentemente por WhatsApp (donde a diferencia de los anteriores, presentan ideas que no se pueden debatir cuando no se forma parte del grupo) podrían estar articulando la percepción que se difunde por las redes, con la experiencia cotidiana de la gente. ¿Quién no ha vivido la discriminación por el color de su piel, por su clase social, por su condición de género? De alguna manera, los marcos de la experiencia en las interacciones cotidianas permiten que las formas simbólicas que circulan a través de las redes, cobren sentido. En las elecciones de 2021, el partido Morena volvió a arrasar logrando ganar 11 de las 15 gubernaturas que entraron a la contienda. A pesar de las campañas negras o campañas de odio que los voceros de la derecha y los medios de comunicación masiva emprendieron antes y durante la campaña electoral, Morena ganó las elecciones y logró asegurar su mayoría en la cámara de diputados.

No obstante lo anterior, habrá que indagar a nivel microsociológico los efectos que la polarización sigue teniendo en lo local y microsociológico. Los marcos de la experiencia izquierda - derecha y su respectiva gramática racista, inciden en los comportamientos electorales, pero también en la vida cotidiana y en las relaciones cara a cara. En el primer caso, por solo citar un ejemplo, se dijo que el resultado electoral en la CDMX, las alcaldías que fueron ganadas por la coalición "Va por México", los grupos de la derecha radical crearon una imagen que divide a la ciudad entre ricos y pobres, entre quienes pagan impuestos y los que viven de la asistencia pública. A través de memes difundidos por las redes sociodigitales y magnificados por las televisoras, se fomentaron ideas racistas en los discursos y se nutrieron imaginarios políticos clasistas. A nivel micro-sociológico, la polarización llegó a las pequeñas comunidades rurales y urbanas, a los núcleos familiares, a los equipos deportivos, grupos de amigos, generando confrontaciones y disputas a veces muy agresivas y violentas.

14 https:/www.infobae.com/america/mexico/2021/o7/o8/que-es-un-whitexican-y-por-que-calificaron-asi-a-la-pareja-que-tomo-foto-a-nino-pidiendo-dinero-en-guadalajara/

15 https:/www.facebook.com/watch/?extid=SEO----\&v=137992735093122

16 https:/|aristeguinoticias.com/2605/kiosko/poder-prieto-contra-el-racismo-en-mexico-galeria/ 
Las campañas político-electorales y sus estrategias publicitarias han generado una enorme polarización política y fragmentación a varios niveles de la sociedad que en ocasiones obnubilan el análisis e impiden el dialogo constructivo y democrático. Dicha polarización atraviesa todos los sectores sociales, a todas las generaciones y clases sociales, incluyendo a sectores de la "clase media imaginada" (Villanueva, 2020) cuya distinción no es tanto económica como simbólica.

En la sociedad global actual "donde las opiniones y comportamientos son capturados por algoritmos, y quedan subordinados a corporaciones globalizadas", (García Canclini, 2019) ciertamente el espacio público se vuelve opaco y lejano. Y también polariza y abona en favor de los "autoritarismos elegidos", por lo que se hace necesario buscar los caminos para un dialogo constructivo e informado.

La polarización y la racialización de las campañas son fenómenos que se han convertido en un asunto de interés antropológico, al estar ligados a la reproducción y/o transformación de las relaciones de hegemonía / subalternidad, tanto en México como en otros países. En Estados Unidos la campaña racista y xenofóbica contra los mexicanos le dio votos a Trump y lo llevaron al poder. Pero al mismo tiempo favoreció la multiplicación de grupos ultraconservadores y el uso de la violencia física y simbólica hacia las personas identificadas como mexicanas (Oehmichen, 2018). En Bolivia, otro tipo de racismo se expresa entre sectores de la clase media que se sintieron afectados por una supuesta "invasión plebeya" que ocurrió cuando los indígenas comenzaron a ocupar sus espacios exclusivos, tanto físicos como simbólicos. En este sentido, la disputa de la clase media no obedecía tanto a lo que circulaba por las redes sociales, sino por el efecto combinado de discursos que circulaban en redes y los cambios inmediatos en la vida cotidiana. El actuar político de la clase media, proclive a apoyar la llegada de Añez a través de un golpe de Estado pudo haber sido motivada por la necesidad de recuperar “...los espacios simbólicos donde se reproduce la distinción social" (Villanueva, 2020: 284-285), y donde el racismo se acentúa por la llegada de organizaciones indígenas en poder (Loayza, 2021).

Un fenómeno similar ocurrió en el Perú, donde las expresiones racistas y clasistas de la clase media imaginada salieron a flote en los comicios de 2021 para atacar a Pedro Castillo y a sus votantes. Con consignas y cantos amenazantes como el de "Terruquitos, terruquitos, no se escondan, no se escondan, quiero verlos, quiero verlos, en la fosa, en la fosa”, los manifestantes expresaron su rechazo a la elección de Pedro Castillo como presidente del Perú. Cabe aclarar que el término "terruco" ha sido utilizado como sinónimo de terrorista y ha sido empleado para descalificar a los movimientos populares. Para los grupos racistas, son "terrucos" los sectores populares, los pobladores andinos y rurales, y el propio Pedro Castillo (Diario UChile, 2021). En las elecciones presidenciales de Perú se mostró la abierta exposición del racismo, de la discriminación y del menosprecio hacia las clases populares, hacia “... los cholos, la indiada”, donde los grupos racistas negaron el triunfo del presidente electo y llamaron incluso a un golpe de Estado (Villasante, 2021).

El caso de México guarda ciertas semejanzas respecto a esos procesos electorales antes mencionados, pues el esquema con el cual se atacó a López Obrador y a su partido (Morena) mantiene la misma estructura de racialización de las campañas políticas donde los indígenas y sectores populares desplazaron a las élites por la vía electoral. De ahí la validez de utilizar los marcos de referencia, a nivel del discurso, en combinación con la experiencia vivida en lo cotidiano, para afinar el análisis de acuerdo con el Frame analysis goffmaniano.

\section{Conclusiones}

La polarización política que se vive en México puede ser vista como el resultado de la agudización de la desigualdad y la exclusión que dejaron tres décadas de políticas neoliberales. La expulsión migratoria de las zonas rurales, la precarización del trabajo, el desmantelamiento de las instituciones promotoras de los mínimos de bienestar, acentuaron las desigualdades. A ello se debe sumar la descomposición del sistema 
político, que favoreció la acumulación por desposesión y terminó por concentrar aún más los recursos en pocas manos. Las privatizaciones de los bienes propiedad de la nación, que incluye los bienes del subsuelo, la minería, los hidrocarburos y otros recursos, dejó a la inmensa mayoría del país inerme ante la voracidad de los inversionistas nacionales y extranjeros. El triunfo arrollador del candidato de Morena, Andrés Manuel López Obrador, ha sido la expresión de ese México profundo que encontró en el proceso electoral una manera de resarcir los daños ocasionados por las políticas neoliberales. A ello se sumó el hecho de que un proceso global en el que los modelos de acumulación neoliberal han hecho crisis. En el país, el voto masivo para sacar del poder a quienes habían llevado a cabo las acciones que favorecieron la acumulación por despojo, se presentó como una vía para llevar a cabo una transformación profunda del país, sin violencia.

Antes, durante y después del triunfo de Morena, los grupos conservadores se reagruparon para presentar un frente ante lo que consideran una afrenta a sus intereses. Desde entonces, las campañas mediáticas en contra del presidente y de su partido, ha sido cosa de todos los días. En mayo de 2019, durante sus conferencias matutinas, se abrió un espacio en el que se informa sobre el manejo de la prensa y la difusión de noticias falsas y tendenciosas, en una sección que se denomina "Quién es quién en las noticias". Con ello se busca exhibir la complicidad de los medios de comunicación con los intereses de los grupos conservadores.

En un proceso muy complejo, se exhibió también el racismo que se difunde y amplifica por los medios de comunicación y que ha llevado a niveles preocupantes de polarización e incluso de violencia. En el texto publicado el 15 de marzo de 2021, en el periódico estadounidense The New York Times, Enrique Krauze señaló que Estados Unidos ha permanecido "indiferente al sistema autoritario de México", por lo que pidió a Biden, limitar "las tendencias autoritarias de López Obrador y promover un enfoque de moderación" (Krauze, 2021).

Este hecho es un ejemplo de la exacerbación verbal y expresión de la polarización que ha vivido el país antes, durante y después de la llegada de Morena al poder político del país. Eso no significa que otros poderes fácticos, como el de los empresarios y los medios de comunicación hayan dejado de existir. Aliados con una parte del poder judicial y gobiernos de los estados, los medios de comunicación, las televisoras y algunos medios internacionales como The Economist, El País o The Washington Post conforman uno de los polos. El otro lo constituye el presidente López Obrador, junto con otros medios de comunicación, YouTubers y un grupo de empresarios que no comulgan con la polarización que promueven algunos miembros prominentes de las élites empresariales. Es motivo de preocupación la polarización que se vive en el país y que en cualquier momento podría desbordarse.

En este contexto la racialización de las campañas electorales han llevado a que sectores de la derecha pretendan descalificar a quienes han votado por los candidatos de la izquierda. Se ha dicho, por ejemplo, que los programas sociales son una forma de comprar el voto popular. Preocupa que nos encontramos con clase media y alta muy clasista, crítica de las políticas redistributivas que, si bien pueden ser criticables por su manera de operar, no se presentan alternativas que permitirían mejorarlas.

Los grupos conservadores son claros promotores del racismo y del clasismo, del cual participan sectores del empresariado y de los medios de comunicación. La manera en que esos discursos se articulan con las acciones de la jerarquía católica no es tan explícita como cuando se trata de combatir el derecho de las mujeres a interrumpir el embarazo, o de oponerse al matrimonio igualitario (Garma, 2007; 2020). La jerarquía católica no tiene un discurso racista explicito, pero si una vinculación orgánica con los grupos laicos conservadores. Habría que añadir que en México más de 100 obispos conforman la Conferencia Episcopal Mexicana. De ellos, sólo dos hablan alguna lengua indígena. Ambos son hablantes de purépecha, lengua que se habla en el centro occidente de México. Este es un grave problema de la Iglesia católica, pues sus clérigos en la gran mayoría provienen de los seminarios del centro occidente del país, y no son indígenas. Este desequilibro se ha acentuado por el rechazo a la Teología de la Liberación. 
La supremacía blanca mexicana, exhibida por el grupo de creador de "Cosas de Whitexicans" requiere de un análisis más detenido, regionalizado y visto desde una perspectiva microsociológica, para encontrar sus articulaciones internas. El racismo es un problema de la larga cuenta histórica que se actualiza cuando los sectores privilegiados sienten que sus intereses están siendo afectados. Pero aun cuando no se exprese de manera abierta, o quede oculto bajo el manto del mestizaje, se actualiza y se reproduce en las interacciones cotidianas. Como bien lo señala Álvarez-Pimentel (2020) es urgente abordar el estudio de la supremacía blanca para comprender como la gente común justifica la desigualdad y cómo las sociedades ejercen opresión sobre las comunidades no blancas. La propaganda político electoral da material suficiente para realizar los marcos de referencia de una sociedad polarizada en términos de clase y raza.

Hasta ahora, la Antropología poco se ha encargado de analizar estas problemáticas. Parecería que se mantiene la inercia de continuar trabajando los mismos temas sin que el panorama político del país hubiese cambiado. En una revisión sobre la bibliografía publicada en los últimos 30 años, son pocos aun los trabajos que analizan los temas relacionados con la política social. Ni aún los esfuerzos por estudiar la Antropología del Estado se han acercado a analizar la manera en que se han puesto en marcha los diferentes programas de política pública llevadas a cabo tanto por los gobiernos neoliberales, como la que emprende el gobierno de López Obrador. De igual forma, la Antropología ha estado ausente en el estudio de la polarización política del país y de la manera de actuar de la extrema derecha. Quienes más se han acercado a su estudio, son los antropólogos que analizan el papel de la Iglesia católica y su relación con el Estado. Pero poco o nada se ha investigado sobre la articulación entre el racismo promovido por los grupos de la extrema derecha y el clasismo. Y si bien se ha ido avanzando en los estudios sobre el racismo en México que han contribuido a visibilizar esta problemática que había quedado oculta (Navarrete, 2016; Quecha, 2017; Telles y Martínez, 2019; Gall, 2016; Yankelevich, 2014) aún falta mucho por hacer. Los estudios sobre el racismo y su articulación con el gran problema de la desigualdad es una tarea por realizar. No se ha analizado, por ejemplo, la conformación de las clases medias, su comportamiento político y las relaciones patrón-cliente que mantiene con sectores populares, por ejemplo, con todos los trabajadores que les brindan servicios. Asimismo, urge analizar la forma en que los discursos racistas y discriminatorios encubren o enmascaran problemas más profundos derivados de la exclusión clasista que han dejado las políticas neoliberales.

Recibido: 03 de agosto de 2021

Aprobado: 23 de agosto de 2021 


\section{Referencias}

ABRAMSKY, Sasha. 2020. "Fascism Is the Core of Trump's Message”. The Nation, September 23.

ACHCAR, Gilbert. 2021. "El ascenso político de la extrema derecha. ¿Cómo podemos hacer revivir la "inmunidad de rebaño" frente al fascismo"? Viento Sur, 25 de febrero de 2021, https:|/vientosur.info/ como-podemos-hacer-revivir-la-inmunidad-de-rebano-frente-al-fascismo/, consultado el $12 \mathrm{de}$ julio de 2021.

ÁLVAREZ-PIMENTEL, Ricardo. 2020. "Unspoken Whiteness: \#Whitexicans and Religious Conservativism in Mexico". Journal of Hispanic and Lusophone Whiteness Studies (HLWS), año 1, article 4: 47-69

ARISTEGUI NOTICIAS. 2018. "AMLO define el concepto fifí". https:/|aristeguinoticias.com/2111/mexico/ amloenaristeguinoticias-define-el-concepto-fifi-enteratel. Consultado el 7 de agosto de 2021.

BARRANCO, Bernardo. 2021. "El Yunque: siniestro brazo de la iglesia". La Jornada, 18 de agosto de 2021. https://www.jornada.com.mx/notas/2021/08/18/politica/el-yunque-siniestro-brazo-de-la-iglesia/, consultado el 19 de agosto de 2021.

BARTRA, Armando. 2006. "La izquierda mexicana en la encrucijada: de la resistencia al fraude electoral a la Convención Nacional Democrática”. OSAL, Observatorio Social de América Latina, VII(20): 1515-3282. Disponible en la World Wide Web: http://bibliotecavirtual.clacso.org.ar/ar/libros/osal/osal2o/bartra.pdf Consultado el 10 de julio de 2021.

BASAVE-BENÍTEZ, Agustín. 1992. México mestizo. Análisis del nacionalismo mexicano en torno a la mestizofilia. México, D.F.: Fondo de Cultura Económica.

BERNAL ÁNGELES, Rogelio. 2017. El cardenismo desde la perspectiva de la derecha mexicana 1934.1940. Tesis para obtener el título de Licenciado en Historia. Facultad de Humanidades de la Universidad Autónoma del Estado de México.

BLANCARTE, Roberto. 2018. Diccionario de religiones en América Latina. México: Fondo de Cultura Económica/ El Colegio de México.

BOKSER, Judit. 2001. "El antisemitismo: recurrencias y cambios históricos". Revista Mexicana de Ciencias Políticas y Sociales, 44(182): 101-132.

BONFIL, Guillermo. 1987. México Profundo. Una civilización negada. México: Grijalbo.

COLL, Andreu; URBÁN, Miguel. 2019. “Las nuevas derechas radicales. Presentación”. Viento Sur, 166(XXVII). https://vientosur.info/, consultado el 13 de julio de 2021

DELGADO, Álvaro. 2003. El Yunque. La ultraderecha en el poder. México: Plaza y Janes.

DIARIO UCHILE. 2021. "Perú: el racismo sale a flote para atacar a Pedro Castillo y a sus votantes". 1 de julio 2021, https:/|radio.uchile.cl/2021/o7/01/peru-el-racismo-sale-a-flote-para-atacar-a-pedro-castillo-y-a-susvotantes/, Consultado el 11 de agosto de 2021.

ESTEINOU MADRID, Javier. 2019. "Las elecciones de 2018 y el triunfo de AMLO/Morena”. Argumentos. Estudios Críticos de la Sociedad, 89: 13-28. https:/|argumentos.xoc.uam.mx/index.php/argumentos/article| view/1052, Consultado el 3 de agosto de 2021

ETELLEKT. 2021. Sexto informe de violencia política en México, junio 5 de 2021. https:/|www.etellekt.com/ informe-de-violencia-politica-en-mexico-2021-J5-etellekt.html

FLORES, Nancy. 2021. "El Yunque: sus métodos de espionaje, contraespionaje, contraguerrilla y manipulación social”, Contralínea, 21 de agosto de 2021, https://contralinea.com.mx/el-yunque-susmetodos-de-espionaje-contraespionaje-contraguerrilla-y-manipulacion-social/

GALL, Olivia. 2016. "Discursos de odio antisemita en la historia contemporánea y el presente de México". Desacatos, 51: 70-91 
GARCÍA CANCLINI, Néstor Raúl. 2019. Ciudadanos reemplazados por algoritmos. Alemania: Universidad de Guadalajara, Centro Mria Sibylla Merian de Estudios Latinoamericanos Avanzados en Humanidades y Ciencias Sociales (CALAS), Flacso Ecuador, Editorial UCR.

GARCÍA CANTÚ, Gastón. 1997. "La derecha”. En: Lecturas universitarias 40. Antología. El pensamiento de la reacción mexicana (la derecha). Historia documentada, tomo III. (1929-1940). México D.F., UNAM.

GARCÍA VERGARA, Talía Joanna. 2008. "Los intelectuales de derecha en México”, El Cotidiano, 149: 83-9o.

GARMA NAVARRO, Carlos. 2020. "México: los nuevos caminos de los creyentes. Transformaciones en las posiciones políticas de las iglesias evangélicas, protestantes y pentecostales”. Plural. Antropologías desde América Latina y el Caribe, 3(6): 183-206

GARMA NAVARRO, Carlos; HERNÁNDEZ, Alberto. 2007. "Los rostros étnicos de la adscripción religiosa”. En: Renée de la Torre y Cristina Gutiérrez Zúñiga (coord..), Atlas de la diversidad religiosa en México. Guadalajara: El Colegio de Jalisco, El Colegio de la Frontera Norte. 203-226.

GOFFMAN, Erving. 2006. Frame Analysis. Los marcos de la experiencia. Madrid: Centro de Investigacinoes Sociológicas/Siglo XXI España.

GÓMEZ TAGLE, Silvia (coord.). 2013. La cultura política de los jóvenes. México, D.F.: El Colegio de México. GUTIÉRREZ VIDRIO, Silvia. 2007. "La construcción de la imagen de López Obrador en los spots de sus adversarios". Cultura y Representaciones Sociales, 1(2): 31-54

GUZMÁN BRACHO, Mauricio. 2019. "El asalto democrático de Morena. Análisis de marcos de una estrategia política”. Argumentos. Estudios críticos de la sociedad, 89: 31-56.

HILLER, Fernando Rudy. 2011. "En busca del voto del miedo: la construcción mediática de López Obrador como un peligro para México durante la campaña presidencial de 2006”. Foro Internacional, 51(4): 715-748.

HOFFMANN, Odile. 2008. "Entre etnización y racialización: los avatares de la identificación entre los afrodescendientes en México". En: Alicia Castellanos (coord..), Racismo e Identidades. Sudáfrica y Afrodescendientes en las Américas. México: UAM-Iztapalapa. pp. 163-175.

IGREJA, Rebecca Lemos; NEGRI, Camilo. 2020. "As ciências sociais brasileiras frente à ascensão da extremadireita: uma reflexão urgente e necessária”. Plural. Antropologías desde América Latina y el Caribe, $3(6): 35-69$

ITURRIAGA, Eugenia. 2015. "La ciudad blanca de noche: las discotecas como espacios de segregación”. Alteridades, 25(50): 105-115.

KRAUZE, Enrique. 2006. “López Obrador, el mesías tropical”. Letras Libres, 90: 9-18.

KRAUZE, Enrique. 2021. “Mexico's President May Be Just Months Away From Gaining Total Control”. The New York Times, March 15, 2021 https:/www.nytimes.com/2021/03/15/opinion/international-world/ mexico-biden-amlo.html

LOAYZA BUENO, Rafael. 2021. "Bolivia: el imaginario racial 'blanco' bajo el gobierno de los «indios». Nueva Sociedad, 292: 96-106

LÓPEZ-BELTRÁN, Carlos; GARCÍA DEISTER, Vivette. 2013. “Aproximaciones científicas al mestizo mexicano". História, Ciências, Saúde - Manguinhos, 20(2): 391-410.

MARGULIS, Mario; URRESTI, Marcelo. 1998. La segregación negada. Cultura y discriminación social. Buenos Aires: Editorial Biblos.

MEYER, Jean. 1973. La Cristiada. La guerra de los cristeros, El conflicto entre la Iglesia y el Estado y Los cristeros. México, D.F.: Siglo XXI.

MISELEM, Sofía. 2019. "Fifís vs. Chairos en México". Chicago Tribune, 9 de septiembre de 2019. MONSIVÁIS, Carlos. 2008. El Estado laico y sus malquerientes. México, D.F.: UNAM. 
MORENO, Octavio Humberto; CORRES, Gustavo. 2020. "Una aproximación al uso de guerra sucia contra candidatos presidenciales de izquierda. Los casos de Lula en Brasil y López Obrador en México”. En: Francisco Sánchez Espinoza (coord.), La construcción de lo público a debate. La ciudadanía como sustancia de la democracia. México, Puebla: Universidad Autónoma de Puebla. 107-127

NAVARRETE, Federico. 2016. México racista. Una denuncia. México: Grijalbo.

OEHMICHEN, Cristina. 2018. "Los imaginarios de la alteridad y la construcción del chivo expiatorio: Trump y el racismo antiinmigrante". Pueblos y Fronteras, 13: 1-21

OEHMICHEN, Cristina. 1999. Reforma del Estado. Política social e indigenismo en México 1988-1996. México: Universidad Nacional Autónoma de México/ Instituto de Investigaciones Antropológicas.

PÉREZ RAYÓN, Nora; DE LA TORRE, Virginia; CARRILLO LUVIANOS, Mario Alejandro. 2015. "La derecha en México (1982-1990), continuidades y rupturas”. Sociológica, 6(15): 125-158

PAUSIC, Alejandro; HERNÁNDEZ PÉREZ, J. L. 1988. “La vanguardia de la derecha”. El Cotidiano, 24: 10-19.

QUECHA REYNA, Citlali. 2017. "El racismo y las dinámicas interétnicas: una aproximación etnográfica entre afromexicanos e indígenas en la Costa Chica de México". Antropologías del Sur, 4(8): 149-168.

RODRÍGUEZ DOMÍNGUEZ, Emanuel. 2012. "Retos y encrucijadas conceptuales del estudio de la política como sistema cultural”. Andamios, 9(18): 263-291

SERRANO SÁNCHEZ, Carlos. 2004. "Mestizaje y características físicas de la población mexicana”. Arqueología Mexicana, 65: 64-67.

TEJERA, Héctor. 2005. "De la cultura política a la política de la cultura”. En: Víctor Espinosa, Miguel Rionda (coords.), Después de la alternancia; elecciones y nueva competitividad. México: Eón. 285-324.

TELLES, Edward; MARTÍNEZ CASAS, Regina. 2019. Pigmentocracias. Color, Etnicidad y Raza En América Latina. México: Fondo de Cultura Económica.

TIRADO, Ricardo. 1984. "Semblanza de las organizaciones empresariales mexicanas".

Estudios Políticos, 3 (1), (México, D.F.) FCPyS, UNAM, México; 5-14.

TIRADO, Ricardo. 1987. "Los empresarios y la política partidaria”. Estudios Sociológicos, 15: 477-497.

TIRADO, Ricardo. 1990. "Los empresarios y la política”. El Cotidiano, 35: 54-58.

TOLEDO, Víctor M. 2006. “Todos somos mesías tropicales”. La Jornada, 15 de diciembre de 2006. https:|/cutt. ly/LbNWmQ1, consultado el 14 de agosto de 2021.

TOLEDO, Víctor M.. 2021. "El mesías tropical y los demócratas del neoliberalismo". La Jornada, 18 de mayo de 2021. https:/www.jornada.com.mx/2021/05/18/opinion/014a1pol, consultado el 19 de mayo de 2021

TREVIÑO RANGEL, Javier. 2005. "Los 'hijos del cielo' en el infierno: un reporte sobre el racismo hacia las comunidades chinas en México, 1880-1930". Foro Internacional, 45(3): 409-444.

TREVIÑO RANGEL, Javier. 2009. "Pánico moral en las campañas electorales de 2006: la elaboración del 'peligro para México"'. Foro Internacional, 49: 638-689.

VAN DIJK, Teun. 2007. “Introducción”. Racismo y discurso en América Latina, España: Gedisa. pp. 21-34.

VARELA, Roberto. 2005. "Participación y cultura política”. En: Pablo Castro Domingo (coord.), Cultura política, participación y relaciones de poder. Toluca, México: El Colegio Mexiquense, Consejo Nacional de Ciencia y Tecnología, UAM - Iztapalapa

VELÁZQUEZ, Elisa. 2016. "Balances y retos de los estudios antropológicos sobre poblaciones afrodescendientes en México". Anales de Antropología, 50(2): 177-187.

VILLANUEVA RANCE, Amaru. 2020. "Bolivia: la clase media imaginada". Nueva Sociedad, 285, enero febrero de 2020. https:/|nuso.org/articulo/bolivia-la-clase-media-imaginada/, consultado el 12 de agosto de 2021 
VILLASANTE CERVELLO, Mariela. 2021. "El racismo: conceptos y elecciones de 2021 desde la antropología social”. En: Instituto de Democracia y Derechos Humanos de la Universidad Católica del Perú, IDEHPUCP, https:||idehpucp.pucp.edu.pe/notas-informativas/el-racismo-conceptos-y-elecciones-de-2021-desde-laantropologia-social/ consultado el 18 de agosto de 2021.

YANKELEVICH, Pablo. 2014. "Extranjería y antisemitismo en el México posrevolucionario". Interdisciplina, 2(4): 143-159.

YAÑEZ, Brenda. 2019. "Llueven críticas a Quadri por tuit sobre Oaxaca, Guerrero y Chiapas". Expansión política, en: https://politica.expansion.mx/mexico/2019/01/12/llueven-criticas-a-quadri-por-tuit-sobreoaxaca-guerrero-y-chiapas

WEITZ, Eric; FENNER, Angelica. 2004. Fascism and Neofascism: Critical Writings on the Radical Right in Europe (Studies in European Culture and History). New York: Palgrave Macmillan.

\section{Cristina Oehmichen-Bazán}

Instituto de Investigaciones Antropológicas

Universidad Nacional Autónoma de México (UNAM)

https://orcid.org/0000-0002-4223-3668

Email: Cristina.oehmichen@gmail.com 